\title{
KADAR ASAM URAT SUKU SERAWAI DAN SUKU JAWA DI KABUPATEN KEPAHIANG
}

\author{
Uric Acid Levels of Serawaineseand Javanese People \\ in Kepahiang Regency
}

\author{
Kiki Puspasari, Ali Khomsan, Faisal Anwar \\ Bagian Gizi Masyarakat Fakultas Ekologi Manusia, IPB \\ (kikipuspasari55@yahoo.com)
}

\begin{abstract}
ABSTRAK
Peran asam urat dalam meningkatkan penyakit ginjal dan kardiovaskuler dalam beberapa tahun terakhir ini sering menjadi perdebatan para ahli. Penyakit kardiovaskuler dan infark miokard dilaporkan dipengaruhi oleh tingginya asam urat dalam darah dalam beberapa penelitian besar. Jenis penelitian menggunakan rancangan cross sectional study. Tujuan penelitian ini melihat perbedaan kadar asam urat antara suku Jawa dengan suku Serawai. Penarikan sampel menggunakan purposive sampling dengan 104 orang berusia 40-65 tahun. Data primer berupa data subjek termasuk umur, jenis kelamin, pendapatan, pendidikan, pekerjaan, kadar asam urat. Untuk menganalisis perbedaan dan kadar asam urat darah pada kedua suku dengan menggunakan uji t tidak berpasangan. Suku Serawai 55,8\% mempunyai kadar asam urat tinggi dan Suku Jawa yang mempunyai kadar asam urat tinggi sebanyak 40,4\%. Dari analisis uji beda kadar asam urat antara Suku Serawai dengan Suku Jawa diperoleh $p=0,031$ $(\mathrm{p}<0,005)$, terdapat perbedaan kadar asam urat antara Suku Jawa dengan Suku Serawai.
\end{abstract}

Kata kunci : Kadar asam urat, suku

\section{ABSTRACT}

In recent years, the role of uric acid in increasing kidney and cardiovascular disease cases has often been debated by experts. Several large studies have reported that cardiovascular disease and myocardial infarction were affected by the high uric acid levels in the blood. The present study used a cross-sectional design. This study aims to analyze the difference in blood uric acid levels between Javanese and Serawainese people.Purposive sampling was used to gather data from 104 people aged 40 to 65 years old. The primary data was in the form of subject data consisting of age, gender, income, education, occupation, and blood uric acid levels. An unpaired t-test was conducted to analyze the difference in blood uric acid levels between Javanese and Serawainese participants. Findings show that the Serawainese and Javanese participants' blood uric acid levels were high at 55.8\% and $40.4 \%$ respectively. The result of an independent t-test analysis showed that there wasa difference in uric acid levels between the Javanese and Serawainese participants with value of $p=0.031(p<0.005)$.

Keywords : Uric acid levels, ethnic 


\section{PENDAHULUAN}

Peran asam urat dalam meningkatkan penyakit ginjal dan kardiovaskuler dalam beberapa tahun terakhir ini sering menjadi perdebatan para ahli. Sejak 50 tahun yang lalu kadar asam urat telah ditemukan berhubungan dengan berbagai kesakitan termasuk hipertensi, aterosklerosis hiperisulinemia dan gangguan fungsi ginjal. ${ }^{1}$ Meningkatnya kadar asam urat dilaporkan terjadi pada penderita darah tinggi seperti di beberapa penelitian yang telah dilakukan pada $20-89 \%$ pada penderita darah tinggi mempunyai kadar asam urat yang meningkat. ${ }^{2}$ Baik di Negara maju maupun berkembang, penyakit asam urat terus berkembang dan sedikit yang terkontrol dengan baik. Diperkirakan pada tahun 2020 penderita kadar asam urat akan meningkat dibandingkan pada tahun 2007 yaitu 230 juta dan lebih banyak menyerang pada usia pertengahan 40-59 tahun..$^{15}$ Arthritis gout, nefropati gout atau batu ginjal merupakan risiko yang timbul akibat hiperurisemia. ${ }^{6}$ Prevalensi dari hiperurisemia lebih tinggi terjadi pada wanita lansia di Guangzhou Provinsi Guangdog Cina Selatan. Obesitas, konsumsi daging merah, seafood dan konsumsi alkohol berhubungan dengan tingginya prevalensi dari hiperurisemia. ${ }^{3}$

Penelitian yang dilakukan di lima kota di Cina menyebutkan bahwa prevalensi hiperuricemiadan goat $13,19 \%$ prevalensi ini lebih tinggi pada pria dibandingkan wanita $(18,23 \%)$. Hiperurisemia pada populasi ini meningat pada usia 30 tahun untuk pria dan wanita pada usia 50 tahun. $^{7}$ Kadar asam urat juga berhubungan terhadap jenis kelamin, usia, trigliserida dan gaya hidup pada penelitian yang dilakukan pada orang dewasa di Kamerun. ${ }^{4}$ Kota besar meningkatkan prevalensi hiperurisemia sebesar $18,7 \%$ di Provinsi Cina. Terdapat perbedaan kadar asam urat dengan usia dan agama. Pria mempunyai kadar asam urat yang lebih tinggi dibandingkan wanita, tetapi dengan menignkatnya usia menurunkan kadar asam urat pada pria. Pada wanita peningkatan usia menaikkan kadar asam urat. ${ }^{5}$

Angka kejadian hiperurisemia di Indonesia setiap daerah berbeda-beda. Penelitian yang dilakukan di Sinjai (Sulawesi Selatan) 10\% pria mengalami hiperurisemia dan $4 \%$ pada wanita. Bandungan (Jawa Tengah) 24,3\% pria menderita hiperurisemia dan 11,74\% wanita. Angka kejadian hiperurisemia lebih tinggi di daerah Minahasa yaitu $30 \%$ pada pria dan $23,31 \%$ pada wanita. Sebuah studi yang dilakukan oleh Chen et al., menunjukkan bahwa subyek yang memiliki hiperurisemia memiliki rasio 1,6 kali lipat lebih tinggi mengalami sindrom metabolik. ${ }^{8}$ Asam urat di Indonesia menduduki posisi kedua setelah osteoritis dan diderita pada usia yang lebih awal dibandingkan dengan negara barat, yaitu pada usia di bawah 34 tahun. ${ }^{16}$

Belum adanya informasi yang pasti mengenai gambaran asam urat di Indonesia terutama antar suku. Padahal kadar asam urat yang tinggi mempunyai dampak yang memengaruhi kejadian sindrom metabolik. Penelitian ini bertujuan mengetahui kadar asam urat pada Suku Serawai dan Suku Jawa di Kabupaten Kepahiang.

\section{BAHAN DAN METODE}

Jenis penelitian menggunakan rancangan cross sectional study. Penelitian ini dilakukan di Kabupaten Kepahiang pada bulan Maret-Mei tahun 2016. Populasi penelitian ini adalah masyarakat Suku Serawai dan Suku Jawa yang tinggal di Kabupaten Kepahiang. Penarikan sampel menggunakan purposive sampling dengan besar masing-masing sampel 52 orang orang Suku Serawai dan 52 orang Suku Jawa. Kriteria inklusi dalam penelitian ini, yaitu subjek yang merupakan asli Suku Serawai dan Suku Jawa, tinggal sejak lahir di Kabupaten Kepahiang dan berusia antara 40 sampai 65 tahun. Data primer berupa data subjek termasuk umur, jenis kelamin, pendapatan, pendidikan, pekerjaan, kadar asam urat darah, tinggi badan, berat badan. Pengumpulan data dilakukan dengan menggunakan kuesioner. Pengambilan darah untuk menggukur kadar asam urat dengan menggunakan alat tes darah yang bernama easy touch GCU. Darah yang diambil, yaitu darah yang diujung jari. Proses pengolahan data meliputi kegiatan editing, coding, entry dan cleaning menggunakan program IBM SPSS Statistic versi 16.0. Analisis statistik deskriptif dilakukan pada data karakteristik responden meliputi usia, jenis kelamin, pendapatan, pendidikan, pekerjaan, kadar asam urat darah. Menganalisis kadar asam urat darah pada ke-dua suku dengan menggunakan uji t tidak berpasangan. 


\section{HASIL}

Subjek Suku Serawai dan Suku Jawa dalam penelitian ini masing-masing berjumlah 52 orang yang terdiri dari 26 orang laki-laki dan 26 orang perempuan. Hasil karakteristik dan kadar asam urat reponden dapat dilihat pada Tabel 1. Usia pada penelitian ini dibagi menjadi dua kategori, yaitu usia pertengahan ( $<59$ tahun) dan usia lanjut ( $>60$ tahun). Subjek Suku Serawai 92,3\% berusia $<59$ tahun dan 7,3\% termasuk berusia $>60$ tahun. Subjek Suku Jawa yang berusia $<59$ tahun $84,6 \%$ dan subjek berusia $>60$ tahun $15,4 \%$.

Pendidikan dalam penelitian ini dibagi menjadi tiga kategori yaitu pendidikan dasar ( $<9$ tahun), pendidikan menengah (10-12 tahun) dan perguruan tinggi ( $>13$ tahun). Subjek Suku Serawai yang berpendidikan dasar $(50,0 \%)$, pendidikan menengah $(34,6 \%)$, perguruan tinggi $(15,4 \%)$. Subjek Suku Jawa yang berpendidikan dasar $(82,7 \%)$, pendidikan menengah $(15,4 \%)$ dan perguruan tinggi $(1,9 \%)$ (Tabel 1).

Pekerjaan dibagi menjadi lima kategori, yaitu wiraswasta, petani, PNS, ibu rumah tangga dan honorer. Subjek Suku Serawai yang bekerja sebagai wiraswasta $(5,8 \%)$, petani $(75,0 \%)$,
PNS (7,7\%), ibu rumah tangga (11,5\%), sedangkan Suku Jawa yang bekerja sebagai wirswasta $(1,9 \%)$, petani $(88,5 \%)$, ibu rumah tangga $(7,7 \%)$ dan honorer (1,9\%) (Tabel 1).

Penghasilan dikategorikan dalam dua kategori yaitu kurang dari UMR $(<$ Rp.1.350.000) dan lebih dari UMR $(\geq$ Rp.1.350.000). Suku Serawai yang berpenghasilan kurang dari UMR $(73,1 \%)$ dan yang berpenghasilan lebih dari UMR $(26,9 \%)$. Suku Jawa yang berpenghasilan kurang dari UMR $(94,2 \%)$ dan berpenghasilan lebih dari UMR (5,8\%) (Tabel 1).

Kadar asam urat dikategorikan menjadi dua, yaitu normal dan tinggi. Kadar asam urat antara pria dan wanita berbeda. Pria kadar kolesterol normal harus kurang dari $7 \mathrm{mg} / \mathrm{dl}$ dan wanita kadar kolesterol normal kurang dari $6 \mathrm{mg} / \mathrm{dl}$. Suku Serawai $(55,8 \%)$ mempunyai kadar asam urat lebih tinggi dibandingkan dengan Suku Jawa (40,4\%). Dari analisis uji beda kadar asam urat antara Suku Serawai dengan Suku Jawa diperoleh $\mathrm{p}=0,031$ $(\mathrm{p}<0,005)$. Dari analisis uji statistik didapatkan terdapat perbedaan kadar asam urat antara Suku Jawa dengan Suku Serawai (Tabel 1).

Tabel 1. Karakteritik Responden dan Kadar Asam Urat pada Suku Serawai dan Suku Jawa

\begin{tabular}{|c|c|c|c|c|c|c|c|}
\hline \multirow{2}{*}{ Karakteristik } & \multicolumn{2}{|c|}{ Jawa } & \multicolumn{2}{|c|}{ Serawai } & \multicolumn{2}{|c|}{ Total } & \multirow{2}{*}{$\mathbf{p}$} \\
\hline & $\mathbf{n}$ & $\%$ & $\mathbf{n}$ & $\%$ & $\mathbf{n}$ & $\%$ & \\
\hline \multicolumn{8}{|l|}{ Usia (tahun) } \\
\hline Usia Pertengahan $(<59)$ & 44 & 84.6 & 48 & 92.3 & 92 & 88.5 & \\
\hline Usia Lanjut $(>60)$ & 8 & 15.4 & 4 & 7.7 & 12 & 11.5 & \\
\hline \multicolumn{8}{|l|}{ Pendidikan } \\
\hline Pendidikan dasar ( $>9$ tahun) & 43 & 82.7 & 26 & 50.0 & 69 & 66.3 & \\
\hline Pendidikan menengah (10-12 tahun) & 8 & 15.4 & 18 & 34.6 & 26 & 25.0 & \\
\hline Perguruan tinggi ( $<13$ tahun) & 1 & 1.9 & 8 & 15.4 & 9 & 8.7 & \\
\hline \multicolumn{8}{|l|}{ Pekerjaan } \\
\hline Wiraswasta & 1 & 1.9 & 3 & 5.8 & 4 & 3.8 & \\
\hline Petani & 46 & 88.5 & 39 & 75.0 & 85 & 81.7 & \\
\hline PNS & 0 & 0 & 4 & 7.7 & 4 & 3.8 & \\
\hline Ibu rumah tangga & 4 & 7.7 & 6 & 11.5 & 10 & 9.6 & \\
\hline Honorer & 1 & 1.9 & 0 & 0 & 1 & 1 & \\
\hline \multicolumn{8}{|l|}{ Penghasilan } \\
\hline Kurang dari UMR $(<1.350 .000)$ & 49 & 94.2 & 38 & 73.1 & 87 & 83.7 & \\
\hline Lebih dari UMR $(>1.350 .000)$ & 3 & 5.8 & 14 & 26.9 & 17 & 16.3 & \\
\hline \multicolumn{8}{|l|}{ Kadar Asam Urat } \\
\hline Normal & 31 & 59.6 & 23 & 44.2 & 54 & 51.9 & 0.031 \\
\hline Tinggi & 21 & 40.4 & 29 & 55.8 & 50 & 48.1 & \\
\hline
\end{tabular}

* Kadar asam urat pria normal $<7 \mathrm{mg} / \mathrm{dl}$, tinggi $>7 \mathrm{mg} / \mathrm{dl}$

Kadar asam urat Wanita normal $<6 \mathrm{mg} / \mathrm{dl}$, tinggi $>6 \mathrm{mg} / \mathrm{dl}$ 


\section{PEMBAHASAN}

Hiperurisemia merupakan kadar asam urat di atas normal jika kadar asma urat pada laki-laki lebih dari $7,0 \mathrm{mg} / \mathrm{dl}$ dan pada wanita lebih dari 6,0 $\mathrm{mg} / \mathrm{dl} .{ }^{17}$ Banyak faktor yang dapat memengaruhi status gizi yaitu usia, pendidikan, perkawinan, status merokok dan durasi tidur ditemukan memengaruhi indeks massa tubuh. ${ }^{9}$ Kadar asam urat Suku Jawa mempunyai kategori normal dibandingkan Suku Serawai yang mempunyai kategori tinggi. Meningkatnya metabolisme asam urat (overproduction) dan penurunan pengeluaran asam urat urin (underexcreation) merupakan penyebab terjadinya penyakit hiperurisemia. ${ }^{17}$

Beberapa faktor yang memengaruhi kadar asam urat yaitu aktivitas fisik, konsumsi alkohol, usia dan makanan yang tinggi purin. ${ }^{10}$ Pada wanita yang post menaupose asupan protein hewani dan vitamin $\mathrm{C}$ berpengaruh terhadap kadar asam urat darah. ${ }^{11}$ Jumlah urat dalam tubuh dapat memengaruhi keseimbangan dalam produksi dan ekresi. Normalnya kadar asam urat pada laki-laki yaitu $<7$ $\mathrm{mg} / \mathrm{dl}$ dan wanita $<6 \mathrm{mg} / \mathrm{dl} .{ }^{12}$ Terdapat hubungan yang signifikan antara tekanan darah sistolik dan diastolik dengan kadar asam urat. ${ }^{13}$ Asam urat di produksi oleh metabolisme purin yang di produksi di dalam darah yang berasal dari purin endogenous substance atau yang berasal dari makanan. ${ }^{14}$ Makanan merupakan salah satu faktor yang memengaruhi kadar asam urat. Purin merupakan salah satu penyumbang kadar asam urat dalam darah. Mengonsumsi makanan tinggi purin dapat memengaruhi kadar asam urat dalam darah. Dari hasil survei pada Suku Serawai menunjukkan bahwa Suku Serawai lebih menyukai makanan jeroan dibandingkan oleh Suku Jawa. Jeroan merupakan makanan yang mengandung purin tinggi dibandingkan dengan sayuran hijau seperti kacang-kacangan. Sedangkan Suku Jawa tidak terlalu sering mengonsumsi jeroan, tetapi banyak mengonsumsi sayuran hijau.

\section{KESIMPULAN DAN SARAN}

Suku Serawai $(55,8 \%)$ lebih banyak yang mempunyai kadar asam urat tinggi dibandingkan dengan suku Jawa (40,4\%). Hasil analisis uji beda menunjukkan bahwa terdapat perbedaan kadar asam urat Suku Jawa dengan Suku Serawai $(p=0,031)$. Saran kepada pemerintah agar lebih memperhatikan kesehatan masyarakat, karena hiperurisemia ini dapat menyebabkan penyakit sindrom metabolik. Oleh karena itu, sebaiknya rutin dilakukan pemerikasaan terkait kadar asam urat sehingga masyarakat dapat lebih mengetahui tingkat kadar asam uratnya. Dengan mengetahui seberapa besar kadar asa urat, masyarakat dapat lebih mengontrol makanan dan faktor lain yang dapat meningkatkan kadar asam urat.

\section{DAFTAR PUSTAKA}

1. Loachimescu AG, Brennan DM, Hoar BM, Hazen, SL, Hoogwerf, BJ. Serum Uric is an Independent Predictor of all-cause Mortality in Patients at High Risk of Cardiovascular Disease. 2008;58:623-630.

2. Oppatham, S, Bancha, S, Choovichian, P. the Relationship of Hyperuricemia and Blood Pressure in the Thai Army Population. J Postgraduate Med. 2008;54(4):259-262.

3. Xioang, Z, Zhu, C, Qian, X, Zhu, J, Wu, Z, Chen, L. Serum Uric Acid is Associated with Dietary and Lifestyle Factors in Elderly Women in Suburban Guanzhou in Guandgdong Province of South China. The Journal of Nutrition Helath. 2013;17(1):30-34.

4. The Relationship between Uric Acid and Hypertension in Adults in Fako division, SW Region Cameroon. J Nutr Food Sci. 2014;4(1):

5. Qiu, L, Cheng, X, Wu, J, Liu, J, Xu, T, Ding, H, Liu, Y, Ge, Z, Wang, Y, Han H, Liu, J, Zhu, G. Prevalence of Hyperuricemia and its Related Risk Factor in Helathy Adults from Northern and Northeastern Chinese Porvinces. 2013;13(664).

6. Edward, NL. Gout: Clinical Features. In: Klippel JH, Stone JH, Crofford LJ, White PH, editors. $3^{\text {th }}$ ed. Springer. 2008;9:241.

7. Miao, Z, Li, C, Chen, Y, Zhao, S, Wang, Y, Wang, Z, Chen, X, Xu, F, Wang, F, Sun, R, Hu, J, Song, W, Yan, S, Wang, C. Dietary and Lifestyle Changes Associated with High Prevalence of Hyperuricemia and Gout in the Shandong Coastal Cities of Eastern China. The Journal of Rheumatology. 2008;35(9):18591864.

8. Chen, LY. Relathionship between Hyperuricemia and Metabolic Syndrome. Journal of Zhejian University. 2007;8:593-598. 
9. Asil, E, Surucuoglu. MS, Cakiroglu, FP, Ucar, A, Ozcelik, AO, Yilmaz, MV, Akan LS. Factors that Affect Body Mass Index of Adults. 2014;13(5):255-260.

10. Andry, Saryono, Upoyo, AS. Analisis Faktor-Faktor yang Memengaruhi Kadar Asam Urat pada Pekerja Kantor di Desa Karang Tui Kecamatan Bumi Ayu, Kabupaten Brebes. 2009;4(1):26-31.

11. Mulyasari, A. Faktor Asupan Zat Gizi yang Berhubungan dengan Kadar Asam Urat Darah Wanita Postmenopause. Artikel Penelitian. 2015.

12. Chizynski, K, ROzycka, M. Hyperuricemia (in Polish). Pol Merkur Manag Care.2005. 11:435-442.

13. Assob, JCN, Ngowe, MN, Nsagha DS, Njunda AL, Waidim, Y, lemuh DN, Weledji, EP. The Relationship between Urci Acid and Hypertension in Adults in Fako division, SW Region
Cameroon. J Nutr food. 2014;4(1):1-4.

14. Harris, ED, Buff, RC, Firestein, GS, Genovese, MC, Sergent, JS, kelly's Textbook of. 2005. Rheumatology $7^{\text {th }}$ edn. Elsevier Saunders.

15. Yankusuma, D, Putri, P. Pengaruh Rebusan Daun Salam terhadap Penurunan Kadar Asam Urat di Desa Malanggaten Kecamatan Kebakkramat Kabupaten Karangayar. KOSALA. 2016;4(1):90-96.

16. Sukarmin. Faktor-Faktor yang Berhubungan dengan Kadar Asam Urat dalam Darah Pasien Gout di Desa Kedungwinong Sukolilo Pati. The $2^{\text {nd }}$ University Research Cloquium 2015. 2015;95-100.

17. Edward NL. Management of Hyperuricemia. In: Koopman WJ, editor. Arthritis and allied Condition: a Textbook of Rheumatology. $14^{\text {th }}$ ed. Baltimore: Williams and Wilkins. 2001 